Eur. J. Clin. Chem. Clin. Biochem.

Vol. 32, 1994, pp. 313-317

(C) 1994 Walter de Gruyter \& Co.

Berlin - New York

\title{
Synthesis of Tissue Factor Pathway Inhibitor in Human Synovial Cells and Chondrocytes Makes Joints the Predilected Site of Bleeding in Haemophiliacs
}

\author{
By T. Brinkmann ', Heike Kähnert ${ }^{1}$, W. Prohaska, O. Nordfang ${ }^{2}$ and K. Kleesiek ${ }^{1}$ \\ 1 Institut fïr Laboratoriums- und Transfusionsmedizin, Herz- und Diabeteszentrum Nordrhein-Westfalen, \\ Universitätsklinik der Ruhr-Universität Bochum, Bad Oeynhausen, Germany \\ 2 Biopharmaceuticals Research, Novo Nordisk A/S, Gentofte, Denmark
}

(Received August 5, 1993/January 12, 1994)

Dedicated to Professor Dr: Dr. Helmut Greiling on the occasion of his 65th birthday

Summary: The synthesis of tissue factor pathway inhibitor (TFPI) was investigated in cloned human synovial cells and human chondrocytes. TFPI-specific DNA transcription products of these cells were isolated, and a full-length cDNA of about 1000 base pairs was amplified by reverse transcription and polymerase chain reaction. The amplified DNA was cloned into the vector pUC 18 . The TFPI coding sequence was confirmed by double stranded sequencing and was identical with that previously published for human TFPI coding nucleotide sequence from human placental cDNA (1).

The inhibitory activity of TFPI in the cell medium of cultivated human chondrocytes and cloned human synovial cells was determined by a specific chromogenic substrate assay of factor Xa activity. The inhibitory activity of TFPI in the medium of human chondrocytes and cloned human synovial cells was $630-720 \mathrm{mU} / 10^{8}$ cells and $1080-1665 \mathrm{mU} / 10^{8}$ cells, respectively.

In addition, TFPI activity in cell culture media of human chondrocytes and cloned human synovial cells was suppressed by a polyclonal goat anti-TFPI antibody directed against the inhibitory domain I and domain II. In the chromogenic substrate assay, the anti-TFPI antibody completely suppressed the inhibitory activity of TFPI in the samples.

\section{Introduction}

Tissue factor pathway inhibitor (TFPI) is a physiologically important factor in blood coagulation (1), consisting of three tandem Kunitz-type inhibitor domains. Domain I has been identified as the binding site of factor VIIa/tissue factor $\left.{ }^{1}\right)$. The second domain binds factor $\mathrm{Xa}^{\mathrm{l}}$ ); the function of the third domain is still unclear (2).

TFPI is involved in the regulation of coagulation by binding to factor VIIa/tissue factor (2). The inhibitory activity of TFPI occurs in two steps: (i) TFPI inhibits factor Xa and (ii) factor Xa/TFPI complex inhibits factor VII/tissue factor complex by forming a quaternary complex $(3,4)$.

\begin{tabular}{ll}
\hline 1) Enzymes & \\
Factor Xa & EC 3.4 .21 .6 \\
Factor VIIa & EC 3.4 .21 .21 \\
Reverse transcriptase & EC 2.7 .7 .49 \\
Taq polymerase & EC $2.7 .4 .-$ \\
DNA polymerase & EC 2.7 .7 .7 \\
Eco RI & EC $3.1 .21 .-$ \\
Pst I & EC $3.1 .21 .-$ \\
Collagenase & EC 3.3 .24 .3 \\
Pronase & EC 3.4 .24 .31
\end{tabular}


TFPl has been detected in endothelial cells and megakaryocytes. Only minimal amounts are present in mononuclear cells, and none has been detected in hepatocytes (5). However, the expression of TFPI in cells of the synovial system has not hitherto been investigated.

It has been suggested that TFPI may be an important factor for bleeding in haemophiliacs (6) and it has been shown that blocking of TFPI normalises the dilute tissue factor clotting time, which is prolonged in plasma of haemophiliacs (7). Inhibition of coagulation in the synovial system has been assumed in haemophilia. In this disease, the alternative factor $\mathrm{X}$ activation is not possible, due to factor VIII or IX deficiency. Haemophilic patients suffer spontaneous and often massive bleeding, $90 \%$ of which occurs in the joints. The predilection of joint bleeding in haemophiliacs led us to investigate the expression of tissue factor pathway inhibitor in human chondrocytes and human synovial cells.

\section{Materials and Methods}

\section{Materials}

Agarose was purchased from Biozyme Diagnostic, Hameln. Dulbecco's Eagle medium, Ham's F-12 medium, foetal calf serum, human factor VII, human factor X, N-benzoyl-Ile-Glu-Gly-Arg-pnitroanilide (S-2222), $\mathrm{CsCl}$ and antibiotic and antimycotic solution were obtained from Sigma, Deisendorf. Recombinant tissue factor was from Baxter, Unterschleißheim and AmpliTaq DNA Polymerase from Perkin Elmer Cetus, Vaterstetten. Reverse transcriptase was obtained from BRL, Eggenstein and DNA standard and dNTP were from Pharmacia, Freiburg. Polycarbonate filters were purchased from Nunc, Wiesbaden. All chemicals used were of analytical grade or the highest grade commercially available.

\section{Methods}

Cell culture

Human chondrocytes and human synovial cells were obtained from tissue pieces of the knee-joint capsule during meniscotomy. The cells were isolated (8) and cultivated in Dulbecco's modified Eagle medium supplemented with $100 \mathrm{~g} / \mathrm{l}$ heat inactivated foetal calf serum and $10 \mathrm{~g} / \mathrm{l}$ antibiotic and antimycotic solution (containing penicillin $\left(10^{5} \mathrm{U} / \mathrm{l}\right)$, streptomycin $(100 \mathrm{mg} / \mathrm{l})$ and amphotericin $\mathrm{B}$ $(2.5 \mathrm{mg} / \mathrm{l}))$ in a humidified incubator with $5 \% \mathrm{CO}_{2}$. Cells $\left(10^{8}\right)$ were incubated for 72 hours in $9 \mathrm{ml}$ medium. The medium was collected and the inhibitory activity of TFPI was determined.

\section{Cloning synovial cells}

The detailed techniques for cloning and characterising synovial cells will be published elsewhere (10). In brief, to obtain homogeneous cell cultures of human synovial cells $100 \mu$ l of a diluted cell solution were transferred to a well of a microtitre plate and examined under a light microscope. Only wells containing a single cell were used for further investigations. Cell culture medium was added and a polycarbonate filter (pore size $0.1 \mu \mathrm{m}$ ) with an attached monolayer of the same cell preparation was cocultivated. The cells had no direct contact with the single cell and were necessary for optimal growth of the isolated cell. The resulting human synovial cell clones were incubated in cell culture medium, and characterised by fibroblast-specific cell markers (chondroitin-6-sul- phate (9), hyaluronan) and markers specific for macrophages (neopterin, sCD14) (data not shown).

\section{Preparation of human chondrocyte cell cultures}

Chondrocyte cultures were prepared from pieces of human knee joints. The pieces were collected in Ham's F-12 medium, which was enriched with $10 \mathrm{~g} / \mathrm{l}$ antibiotic solution (see section cell culture). Cartilage slices were digested for $90 \mathrm{~min}$ at $37^{\circ} \mathrm{C}$ with 0.01 $\mathrm{g} / 1$ pronase in $100 \mathrm{ml} \mathrm{F}-12$ medium containing $5 \mathrm{~g} / \mathrm{l}$ foetal bovine serum, followed by $0.3 \mathrm{~g} / \mathrm{l}$ bacterial collagenase ${ }^{\mathrm{l}}$ ) in the same medium for $180 \mathrm{~min}$ at $37^{\circ} \mathrm{C}$. The final digest was centrifuged at $900 \mathrm{~s}^{-1}$ for $10 \mathrm{~min}$. The cell pellet was washed three times in serum-free medium. The cells were collected by passing the suspension through a Nitex nylon filter (mesh width $60 \mu \mathrm{m}$ ), then resuspended in serum-containing medium. Cell viability was determined by trypan blue dye exclusion. The cells were cultivated over four days in F-12 medium in tissue culture dishes precoated with agarose to avoid cell attachment. The surviving chondrocytes were collected again on a nylon filter and examined under a light microscope for their spherical morphology.

\section{Ribonucleic acid isolation}

The total amount of cellular RNA was isolated by $\mathrm{CsCl}$ gradient centrifugation (11). Cells ( $10^{8}$ in $10 \mathrm{ml}$ cell culture medium) were centrifuged for $10 \mathrm{~min}$ at $900 \mathrm{~s}^{-1}$ and the pellet was washed with $10 \mathrm{ml}$ buffer $(0.14 \mathrm{~mol} / 1 \mathrm{NaCl}, 0.0027 \mathrm{~mol} / \mathrm{l} \mathrm{KCl}, 0.008 \mathrm{~mol} / \mathrm{l}$ $\mathrm{Na}_{2} \mathrm{HPO}_{4}, 0.0015 \mathrm{~mol} / 1 \mathrm{KH}_{2} \mathrm{PO}_{4}, 0.0005 \mathrm{~mol} / \mathrm{l} \mathrm{MgCl}, 0.0009$ $\mathrm{mol} / 1 \mathrm{CaCl}$, $1 \mathrm{~g} / 1$ glucose, $\mathrm{pH}$ 7.3). The pellet was resuspended in $1.6 \mathrm{ml}$ guanidinium thiocyanate solution $(0.025 \mathrm{~mol} / 1 \mathrm{Tris} / \mathrm{HCl}$, $4 \mathrm{~mol} / \mathrm{l}$ guanidinium thiocyanate, $0.5 \mathrm{~g} / 1 \mathrm{~N}$-lauroylsarcosine, 0.025 $\mathrm{mol} / \mathrm{l}$ EDTA, $0.1 \mathrm{~mol} / 1 \beta$-mercaptoethanol, $\mathrm{pH} 7.6$ ). The solution was aspirated 10 times through a small syringe needle to shear chromosomal DNA. After the addition of $\mathrm{CsCl}$ solution $(5.7 \mathrm{~mol} / \mathrm{l}$ $\mathrm{CsCl}, 0.01 \mathrm{~mol} / \mathrm{l}$ EDTA, $\mathrm{pH} 7.0$ ) to a final volume of $4.5 \mathrm{ml}$, the solution was centrifuged for 18 hours at $150000 \mathrm{~s}^{-1}$. The supernatant was discarded and the RNA pellet was dissolved in $100 \mu \mathrm{ll}$ $0.01 \mathrm{~mol} / 1 \mathrm{Tris}, 0.001 \mathrm{~mol} / 1 \mathrm{EDTA}, \mathrm{pH} 7.4$ (10). After phenol extraction and precipitation with ethanol (12) the isolated RNA was used for cDNA synthesis by reverse transcription.

\section{Reverse transcription}

Isolated RNA $(0.1-5 \mu \mathrm{g})$ and $7 \mathrm{pmol}$ oligo $\mathrm{d}(\mathrm{T})_{12-18}$ primer were incubated at $37^{\circ} \mathrm{C}$ for $90 \mathrm{~min}$ with $10 \mu \mathrm{mol} \mathrm{dNTP}$ and $200 \mathrm{U}$ reverse transcriptase ${ }^{l}$ ) (12). The synthesised cDNA/RNA hybrids were immediately used for the polymerase chain reaction.

\section{Tissue factor pathway inhibitor cDNA synthesis}

A full-length cDNA was synthesised using the polymerase chain reaction (13). The following primers were used (5):

primer I:

\section{5'-TACTGCAGCGCCAAGAACTTTCATCAGAGA-3';}

primer II:

\section{5'-GCGAATTCGCTAATGTTACATTGCTATAAC-3'}

The cDNA complementary sequences of the primers are in bold type. Primer I contains a Pst $\mathrm{I}^{1}$ ) restriction site and primer II an Eco $\mathrm{RI}^{1}$ ) site.

\section{Deoxyribonucleic acid sequencing}

The endonuclease restriction sites, Pst I and Eco Ri, of the generated amplification product were used for cloning into the vector pUC 18. The TFPI coding DNA was confirmed by double stranded sequencing (14) in both upstream and,downstream orientation. 


\section{Determination of tissue factor pathway inhibitor activity}

The inhibitory activity of TFPI was measured by a modified chromogenic substrate assay based on the ability to inhibit factor $\mathrm{X}$ activation by factor VIla/tissue factor complex $(15-17)$. Factor VII $(100 \mu \mathrm{l}, 12.5 \mathrm{U} / \mathrm{l})$ and $100 \mu \mathrm{l}$ recombinant tissue factor (dilution: $1 / 20$ ) were added to $100 \mu \mathrm{l} 0.075 \mathrm{~mol} / 1 \mathrm{CaCl}_{2}$ and $100 \mu \mathrm{l}$ factor $\mathrm{X}(25 \mathrm{U} / \mathrm{l})$. After $10 \mathrm{~min}$ incubation, $100 \mu \mathrm{l}$ cell culture medium ( $1: 5$ diluted in $0.05 \mathrm{~mol} / 1 \mathrm{Tris} / \mathrm{HCl}, 0.1 \mathrm{~mol} / 1 \mathrm{NaCl}, \mathrm{pH}$ 8.0) were added and, after additional incubation for $10 \mathrm{~min}$, virtually all of factor X $(400 \mathrm{U} / \mathrm{l})$ was added in a volume of $100 \mu \mathrm{l}$. After incubation for 10 min the chromogenic reaction was started by the addition of $100 \mu \mathrm{l}$ of the synthetic substrate N-benzoyl-IleGlu-Gly-Arg-p-nitroanilide $(0.0027 \mathrm{~mol} / \mathrm{l})$ and the absorbance was measured at $405 \mathrm{~nm}$. All samples were heat inactivated for $10 \mathrm{~min}$ at $56^{\circ} \mathrm{C}$ before testing.

\section{Inhibition of TFPI activity by anti-TFPI antibody}

In the chromogenic substrate assay for factor $\mathrm{Xa}$ activity the inhibitory activity of tissue factor pathway inbibitor was suppressed by a monospecific goat anti-TFPI antibody. The antibody was obtained by immunisation of a goat with recombinant, two-domain TFPI from yeast (18). Cell culture medium $(100 \mu \mathrm{l}$, diluted $1: 5$ in 0.05 $\mathrm{mol} / 1 \mathrm{Tris} / \mathrm{HCl}, 0.1 \mathrm{~mol} / 1 \mathrm{NaCl}, \mathrm{pH} 8.0$ ) was incubated with 100 ng anti-TFPI antibody for $30 \mathrm{~min}$ at room temperature. This dilution was used in the chromogenic substrate assay as described above.

\section{Results}

Isolation of TFPI-specific RNA and synthesis of TFPI cDNA

TFPI-specific DNA transcription products were isolated from both human chondrocytes and human synovial cells, and a TFPI coding cDNA of about 1000 base pairs was obtained by reverse transcription and polymerase chain reaction (fig. 1). The generated TFPI cDNA was

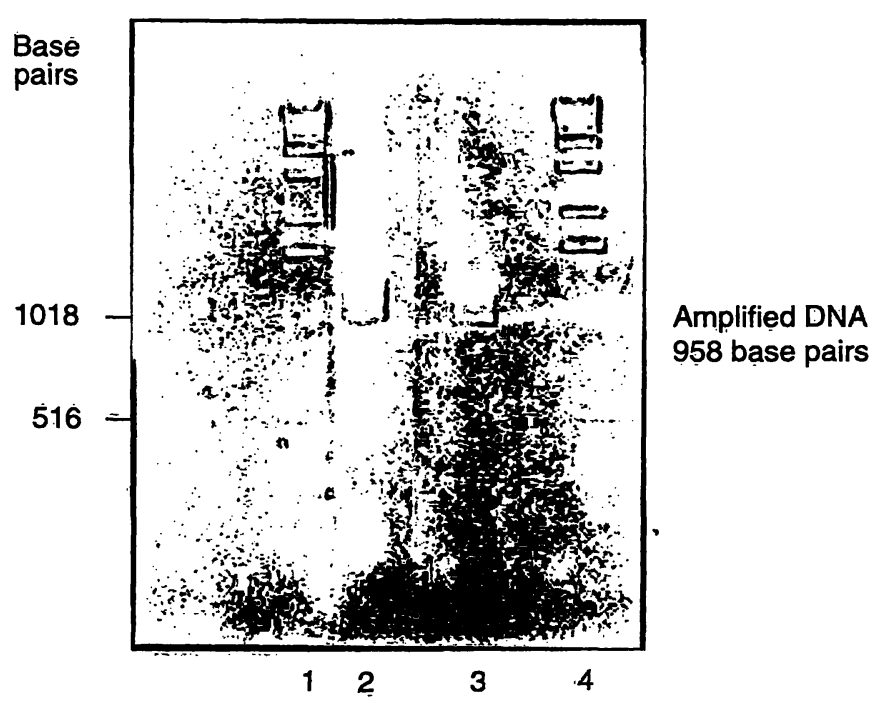

Fig. 1 Agarọse gel electrophoresis of reverse transcription-PCR products of TFPI-specific mRNA.

The gel was stained with ethidium bromide.

Lane 1 and 4, DNA standard;

lane 2, amplified DNA after reverse transcription and polymerase chain reaction of mRNA isolated from human chondrocytes;

lane 3, amplified DNA after reverse transcription and polymerase chain reaction of mRNA obtained from human synovial cells. analysed by double stranded sequencing in both upstream and downstream orientation. No difference from the TFPI coding nucleotide sequence described for human endothelial cells was observed.

After the isolation of the total amount of RNA, an unspecific cDNA synthesis was performed by reverse transcription using an oligo-d(T) $)_{8-12}$ primer. The synthesised TFPI-specific RNA/cDNA hybrids were amplified by the polymerase chain reaction. The used primers hybridised in the non-coding region close to the TFPI coding sequence and generated the desired amplification product.

The polymerase chain reaction primers I and II contained single restriction sites (Pst I and Eco RI, respectively) for cloning the amplified DNA into the vector pUC 18. This vector was used for sequencing the amplified TFPI coding sequence.

\section{Determination of the inhibitory activity of TFPI in cell culture medium}

The inhibitory activity of TFPI in cell culture media from human chondrocytes and cloned human synovial cells was determined by measuring the inhibition of factor $\mathrm{X}$ activation by factor VIIa/tissue factor complex, using a synthetic substrate (S-2222). The inhibitory activity of TFPI in the medium of human synovial cells was $1080-1665 \mathrm{mU} / 10^{8}$ cells $(\mathrm{n}=5)$. In the medium of human chondrocytes the inhibitory activity was 630$720 \mathrm{mU} / 10^{8}$ cells $(\mathrm{n}=3)$.

\section{Inhibition of TFPI activity by a monospecific anti-TFPI-antibody}

Hundred ng monospecific anti-TFPI antibody, specific for the first two Kunitz domains of TFPI, quantitatively suppressed the inhibitory activity of TFPI in cell culture media from human chondrocytes and human synovial cells. In the chromogenic substrate assay, factor $\mathrm{X}$ activity was not influenced by the addition of cell culture medium preincubated with anti-TFPI antibody (fig. 2) thus identifying the inhibitory activity in the medium as TFPI.

\section{Discussion}

The expression of tissue factor pathway inhibitor has so far only been described for endothelial cells and megakaryocytes. We investigated the synthesis of TFPI in human synovial cells and in human chondrocytes. Our investigations showed that these cells also synthesise TFPI-specific DNA transcription products and express TFPI in the cell culture medium. 


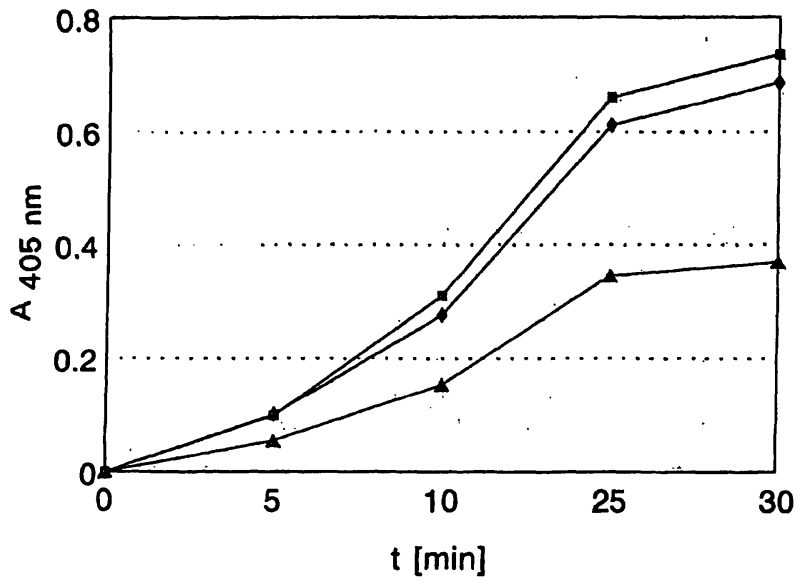

Fig. 2 Effect of anti-TFPI antibody on the inhibitory activity of tissue factor pathway inhibitor in cell culture media.

The amidolysis of the synthetic substrate, N-benzoyl-Ile-Glu-GlyArg- $p$-nitroanilide, by factor $\mathrm{Xa}$ in the chromogenic assay was monitored by measuring the absorbance at $405 \mathrm{~nm}$. Factor Xa activity was measured in the presence of $(-\Delta-)$ and without $(-\square-)$ cell culture medium $(20 \mu \mathrm{l})$. Factor $\mathrm{Xa}$ activity was not influenced by the addition of cell culture medium preincubated with $100 \mathrm{ng}$ anti-TFPI antibody (-৬-).

The synthesis of tissue factor pathway inhibitor in human synovial cells and human chondrocytes seems to be part of an important regulation process in the synovial system, which maintains a balance between fibrinolytic and clotting reactions during minimal bleeding, and avoids inadequate fibrin deposition on the cartilage surface of the joint.

Coagulation is initiated by tissue factor (thromboplastin) which is expressed in fibroblasts, macrophages and endothelial cells (19), and results in activation of the extrinsic pathway of coagulation. Synovial cells are supposed to lack tissue factor (20) which is necessary for the extrinsic pathway of factor $\mathrm{X}$ activation. This hypothesis has served as an explanation for the special joint bleeding in haemophiliacs. However, it was shown that monocytes, which are present in the synovial membrane, are able to produce tissue factor $(20,21)$ and other procoagulant and anticoagulant molecules (22). Whether synovial cells type A (23), which are probably

\section{References}

1. Wun, T.-C., Kretzmer, K. K., Girard, T. J., Miletich, J. P. \& Broze, G. J. jr. (1988) Cloning and characterisation of a cDNA coding for the lipoprotein associated coagulation inhibitor shows that it consists of three tandem Kunitz-type inhibitory domains. J. Biol. Chem. 263, 6001-6004.

2. Rapaport, S. I. (1991) The extrinsic pathway inhibitor: A regulator of tissue factor-dependent blood coagulation. Thrombosis and Haemostasis 66, 6-15.

3. Warn-Cramer, B. J., Rao, L. V. M., Maki, S. L. \& Rapaport, S. I. (1988) Modifications of extrinsic pathway inhibitor (EPI) and factor $\mathrm{Xa}$ that effect their ability to interact and to inhibit derived from monocytes, also synthesize tissue factor is not known.

In haemophiliacs, factor Xa generation depends exclusively on the factor VIIa/tissue factor pathway, since factor VIII or factor IX are deficient. This deficiency prevents an alternative activation of factor $X$. Thus, an inhibition of factor $X$ activation by TFPI results in an additional decrease in the coagulation process in haemophiliacs. It has been shown that the addition of TFPI in a thromboplastin assay prolongs the coagulation time in normal plasma, while the addition of an inhibitory antibody against TFPI shortens it $(17,18)$. Furthermore, anti-TFPI antibody normalised the coagulation time in haemophilic plasma in a dilute thromboplastin assay (17). Therefore, the presence of TFPI in the synovial system would seem to be the reason why joints are the predilected site of bleeding in haemophiliacs. Ninety percent of haemophilic bleeding occurs spontaneously in the joints. Liberated plasma TFPI, in addition to TFPI from synovial cells, represents an anticoagulant potential which in haemophiliacs completely inhibits haemostasis and leads to massive bleeding in the joints, even when only small vessels are injured.

Further investigations will give more information on the physiological function of TFPI in the synovial system and on the influence of inflammatory mediators such as interleukin 1, tumour necrosis factor and bacterial lipopolysaccharides on the cellular expression of TFPI $\bar{I}$ in the synovium. These mediators are known to shift the haemostatic balance in favor of procoagulant activities in endothelial cells (24).

\section{Acknowledgement}

We are endebted to Ms. Anne Kathrin Brunner and Ms. Regina Schroven for excellent technical assistance, Dr. Michael Rieger, Genotype $\mathrm{GmbH}$, Wilhelmsfeld, Germany, for DNA cloning and sequencing and PD Dr. Imo Scheuer, Kreiskrankenhaus Herford, Germany, for providing joint arthroscopy samples. In addition we wish to thank Ms. Grainne Delany for linguistic advice.

This work was supported by the 'Deutsche Forschungsgemeinschaft', Bonn-Bad Godesberg, within the Project SFB 223, B08.

factor VIIa/tissue factor: Evidence for a two step model of inhibition. Thrombosis and Haemostasis 60,543456 .

4. Broze, G. J., Warren, L. A., Novotny, W. F., Higuchi, D. A., Girard, J. J. \& Miletich, J. P. (1988) The lipoprotein-associated coagulation inhibitor that inhibits the factor VIla-tissue factor complex, also inhibits factor $\mathrm{Xa}$ : Insight into its possible mechanism of action. Blood 71, 335-343.

5. Bajaj, M. S., Kuppuswamy, M. N., Saito, H., Spitzer, S. G. \& Bajaj, S. P. (1990) Cultured normal human hepatocytes do not synthesise lipoprotein-associated coagulation inhibitor: Evidence that endothelium is the principal site of its synthesis. Proc. Natl. Acad. Sci. USA 87, 8869-8873. 
6. Broze, G., Warren, L., Novotny, W. F., Higuchi, D. A., Girard, J. J. \& Miletich, J. P. (1988) The lipoprotein associated coagulation inhibitor that inhibits FVII-tissue factor also inhibits FXa. Blood 71, 335-343.

7. Welsh, D. J., Novotny, W. F. \& Wun, T. C. (1991) Effect of LACI on thromboplastin induced coagulation of normal and haemophilic plasma. Thromb. Res. 64, 213-222.

8. Kleesiek, K. \& Greiling, H. (1982) Effect of anti-inflammatory agents on the glycosaminoglycan metabolism in cultured human synovial cells. Rheumatol. Int. 2, 167-174.

9. Kähnert, H., Brinkmann, T., Gässler, N. \& Kleesiek, K. (1994) Determination of chondroitin-6-sulphate by a competitive enzyme immunoassay using a biotinylated antigen. Eur. J. Clin. Chem. Clin. Biochem. 32, 293-299.

10. Brinkmann, T., Kähnert, H. \& Kleesiek, K. (1994) Cloning and biochemical characterisation of human synovial cells. Eur. J. Clin. Chem. Clin. Biochem. (in preparation).

11. Chirgwin, J. M., Prybla, A. E., MacDonald, R. J. \& Rutter, W. J. (1979) Isolation of biologically active ribonucleic acid sources enriched in ribonuclease. Biochemistry 18, 52945299.

12. Sambrock, F., Fritsch, E. F. \& Maniatis, T. (1989) In: Molecular Cloning: A Laboratory Manual, 2nd ed., Cold Spring Harbour Laboratory Press, New York, USA.

13. Saiki, R. K., Bugawan, T. L., Horn, G. T., Mullis, K. G. \& Ehrlich, H. A. (1986) Analysis of enzymatically amplified beta-globin and HLA-DQ alpha DNA with allele-specific oligonucleotide probes. Nature 324, 163-166.

14. Sanger, F., Nicklen, S. \& Coulson, A. R. (1977) DNA sequencing with chain-terminating inhibitors. Proc. Natl. Acad. Sci. USA 74, 5463-5467.

15. Sandset, P. M., Abildgaard, U. \& Pettersen, M. (1987) A sensitive assay of extrinsic coagulation pathway inhibitor (EPI) in plasma and plasma fractions. Thrombosis Research 47, 389400.

16. Lindahl, A. K., Sandset, P. M. \& Abildgaard, U. (1992) The present status of tissue factor pathway inhibitor. Blood, Coagulation and Fibrinolysis 3, 439-449.
17. Pedersen, A. H., Nordfang, O., Norris, F., Wiberg, F. C., Christensen, P. M., Bach-Moeller, K., Meidahl Pedersen, J., Beck, T. C., Norris, K., Hedner, U. \& Kisiel, W. (1990) Recombinant human extrinsic pathway inhibitor. J. Biol. Chem. 265, 16786-16793.

18. Erhardtsen, E., Madsen, M. T., Ezban, M., Hedner, U., Diness, V., Glazer, S. \& Nordfang, O. (1993) Blocking of TFPI shortens the bleeding time in rabbits with antibody induced haemophilia A. Thromb. Haemostas. 69, 556.

19. Bach, R. (1988) Initiation of coagulation by tissue factor. CRC Crit. Rev. Biochem. 23, 339-369.

20. Drake, T. A., Morrissey, J. H. \& Edington, T. S. (1989) Selective cellular expression of tissue factor in human tissues. Amer. J. Pathol. 134, 1087-1097.

21. Edwards, R. L. \& Rickles, F. R. (1984) Macrophage procoagulants. Prog. Hemost. Thromb. 7, 183-209.

22. van Dam-Mieras, M. C. E., Muller, A. C., van Deijk, W. A. \& Hemker, H. C. (1985) Clotting factors secreted by monocytes and macrophages: Analytical considerations. Thromb. Res. $37,9-19$.

23. Burmester, G. R., Dimitriu-Bona, A., Waters, S. J. \& Winchester, R. J. (1983) identification of three major synovial lining cell populations by monoclonal antibodies directed to Ia antigens and antigens associated with monocytes/macrophages and fibroblasts. Scand. J. Immunol. 17, 69-82.

24. Kapiotis, S., Besemer, J., Bevec, D., Valent, P., Bettelheim, P., Lechner, K. \& Speiser, W. (1991) Interleukin-4 counteracts pyrogen-induced downregulation of thrombomodulin in cultured human vascular endothelial cells. Blood 78, 410-415.
Dr. Thomas Brinkmann
Prof. Dr. Knut Kleesiek Institut für Laboratoriums- und Transfusionsmedizin Herz- und Diabeteszentrum Nordrhein-Westfalen Universitätsklinik der Ruhr-Universität Bochum Georgstraße 11 D-32545 Bad Oeynhausen Germany 
